\title{
Unexpected rearrangements in the synthesis of an unsymmetrical tridentate dianionic $\boldsymbol{N}$-heterocyclic carbenet
}

\author{
Emmanuelle Despagnet-Ayoub, ${ }^{\text {ab }}$ Karinne Miqueu, ${ }^{c}$ Jean-Marc Sotiropoulos, ${ }^{c}$ \\ Lawrence M. Henling, ${ }^{d}$ Michael W. Day, ${ }^{d}$ Jay A. Labinger ${ }^{d}$ and John E. Bercaw*d \\ Starting from the same ethylenediamine species, three valuable carbene precursors were synthesized \\ under differing conditions: a tridentate dianionic $N$-heterocyclic carbene bearing an aniline, a phenol \\ and a central dihydroimidazolium salt, its benzimidazolium isomer by intramolecular rearrangement and \\ a dicationic benzimidazolium-benzoxazolium salt by changing the Brønsted acid from $\mathrm{HCl}$ to $\mathrm{HBF}_{4}$. A \\ DFT study was performed to understand the rearrangement pathway. The structure of a bis[(NCO) \\ carbene] zirconium complex was determined.
}

Received 7th December 2012

Accepted 25th February 2013

DOI: $10.1039 / \mathrm{c} 3 s c 22171 \mathrm{~g}$

www.rsc.org/chemicalscience
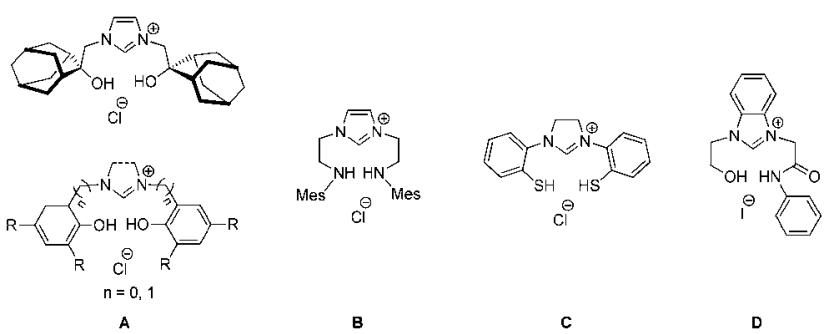

new generations of bidentate or tridentate NHC ligands have attracted attention, especially to access interesting chiral systems ${ }^{2}$ and to isolate rare examples of carbene-early transition metal complexes. ${ }^{3}$ Indeed, Hoveyda et al. reported the synthesis of chiral bidentate NHC-phenolate ligands, whose ruthenium complexes catalyze highly enantioselective ring-opening metathesis/cross-metathesis reactions. ${ }^{2 a}$ Moreover, several examples of early transition metal complexes with tridentate NHCs bearing anionic tethers have exhibited high activity in ring-opening polymerization of rac-lactide ${ }^{4}$ and in olefin polymerization. ${ }^{5}$ For such applications, dianionic tridentate ligands with the carbene donor in the central position are attractive candidates, forcing the binding of the soft NHC to the hard metal centre. Up to now, the only examples of such tridentate dianionic ligands have been reported with coordination patterns $\operatorname{OCO}(\mathbf{A}),{ }^{5 a, 6} \mathrm{NCN}(\mathbf{B}),{ }^{5 e, 7} \operatorname{SCS}(\mathbf{C}){ }^{8}$ and $\mathrm{OCN}(\mathbf{D})^{9}$

${ }^{a}$ CNRS, LCC (Laboratoire de Chimie de Coordination), 205 route de Narbonne, 31077 Toulouse Cedex 4, France

${ }^{b}$ Université de Toulouse, UPS, INPT, LCC, 31077 Toulouse Cedex 4, France. E-mail: emmanuelle-despagnet-ayoub@lcc-toulouse.fr

'Institut des Sciences Analytiques et de Physico-Chimie pour l'Environnement et les Matériaux (UMR 5254), Equipe Chimie Physique, Université de Pau et des Pays de l'Adour, Hélioparc, 2 Avenue du Président Angot, 64053 Pau Cedex 09, France ${ }^{d}$ Arnold and Mabel Beckman Laboratories of Chemical Synthesis, California Institute of Technology, Pasadena, California 91125, USA. E-mail: bercaw@caltech.edu

$\dagger$ Electronic supplementary information (ESI) available: Experimental details (synthesis and copies of ${ }^{1} \mathrm{H}$ and ${ }^{13} \mathrm{C}$ NMR), crystallographic data of 5-7 and computational details. CCDC 857560 and 862749. For ESI and crystallographic data in CIF or other electronic format see DOI: $10.1039 / \mathrm{c} 3 \mathrm{sc} 22171 \mathrm{~g}$
Chart 1 Tridentate dianionic NHC precursors.

(Chart 1). The alkoxide-NHC-amidate ligand D, the only unsymmetric version, is of particular interest because its complexes offer possibilities for stereoselective catalysis. In attempting the synthesis of a precursor to an example of $\mathbf{D}$ with anilide and aryloxide arms, we found that under certain conditions the imidazolium precursor undergoes an unexpected rearrangement, providing access to two other potentially useful NHC precursors. We also studied its coordination behavior on a zirconium complex.

\section{Result and discussion}

The target compound, phenol-aniline dihydroimidazolium $\mathbf{4}$, was synthesized as shown in Scheme 1. Oxalamide 2, obtained from 2-( $N$-mesitylamino)aniline and 2-amino-4,6-di-tert-butylphenol, was reduced by borane-THF or $\mathrm{LiAlH}_{4}$ to $\mathrm{N}$-(2-mesitylaminophenyl)- $N^{\prime}$-(3,5-di-tert-butyl-2-hydroxyphenyl)-ethylenediamine (3). Heating the dihydrochloride salt of 3 with triethyl orthoformate for 15 minutes at $40^{\circ} \mathrm{C}$ precipitated a white powder consisting of 3-(3,5-di-tert-butyl-2-hydroxyphenyl)-1-(2-(mesitylamino)phenyl)-4,5-dihydro- $1 H$-imidazol-3-ium chloride (4), characterized by ${ }^{1} \mathrm{H},{ }^{13} \mathrm{C}$, HSQC and NOESY NMR and elemental analysis. ${ }^{10}$ In the ${ }^{1} \mathrm{H}$ NMR spectrum in $\mathrm{CDCl}_{3}$ the methylene 

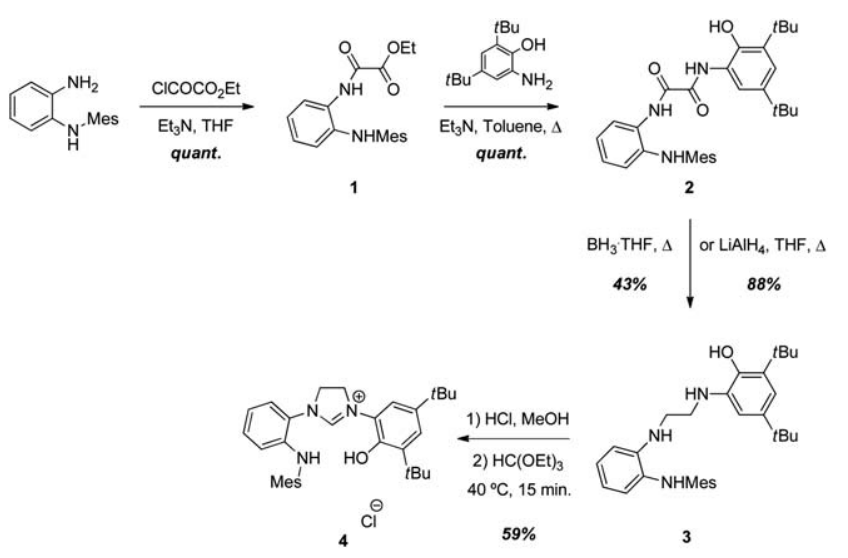

$100 \%\left\{\begin{array}{c}90^{\circ} \mathrm{C}, 15 \text { minutes } \\ \text { or } \\ 8 \text { days at } r \text { in } \mathrm{THF}\end{array} \quad 62 \% \quad \begin{array}{c}\text { 1) } \mathrm{HBF}_{4}, \mathrm{MeOH} \\ \text { 2) } \mathrm{HC}(\mathrm{OEt})_{3} \\ 40^{\circ} \mathrm{C}, 15 \mathrm{~min} .\end{array}\right.$

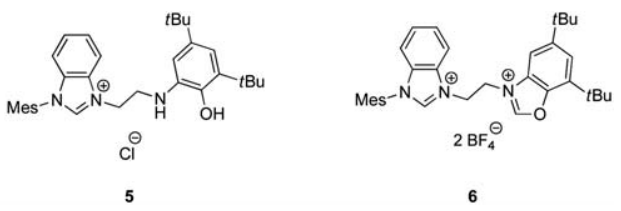

Scheme 1 Tridentate dianionic azolium synthesis.

protons of the imidazolium ring appear as one singlet (at $4.77 \mathrm{ppm}$ ), somewhat surprising in view of the unsymmetric substitution (for example, the analogous 1-mesityl-3-tolyl-4,5dihydro- $1 \mathrm{H}$-imidazolium features two doublets in $\mathrm{CDCl}_{3}$, at 4.62 and $4.91 \mathrm{ppm}$ (ref. 11)). This coincidence of ${ }^{1} \mathrm{H}$ NMR resonance in $\mathrm{CDCl}_{3}$ appears to be accidental; in $\mathrm{MeOH}$ at $-40{ }^{\circ} \mathrm{C}$ two multiplets are observed, at 4.56 and $4.45 \mathrm{ppm}$.

Imidazolium 4 appears completely stable in the solid state, but in chloroform solution new ${ }^{1} \mathrm{H}$ and ${ }^{13} \mathrm{C}$ NMR signals begin to appear in a few days. Clean rearrangement to a new species, with no apparent byproducts, is essentially complete after 10 days at room temperature in chloroform (8 days in tetrahydrofuran); the same product can also be generated by heating 4 in toluene at $90{ }^{\circ} \mathrm{C}$ for 15 minutes. The product was identified by NMR as $\mathbf{5 , 1 2}$ and confirmed by an X-ray diffraction study of

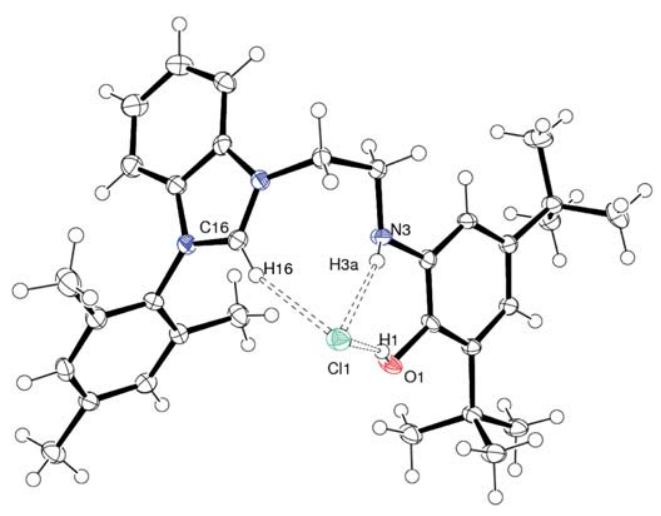

Fig. 1 Molecular structure of benzimidazolium 5. Selected bond lengths $(\AA)$ and angles $\left({ }^{\circ}\right)$ : $\mathrm{C}(16)-\mathrm{N}(1)=1.3366(19), \mathrm{C}(16)-\mathrm{N}(2)=1.3294(19), \mathrm{N}(1)-\mathrm{C}(16)-\mathrm{N}(2)=$ 109.98(15). crystals obtained from an acetone/pentane solution (Fig. 1). This benzimidazolium NHC precursor results from the central carbon of the imidazolium ring of $\mathbf{4}$ "walking" down the molecule to a new position, between one of the central nitrogen centers and the original aniline nitrogen. A notable feature of the structure is the three hydrogen-bonding interactions of the chloride ion: $\mathrm{Cl}(\mathrm{l}) \cdots \mathrm{H}(16)-\mathrm{C}(16)(\mathrm{Cl}(\mathrm{l}) \cdots \mathrm{C}(16)=3.33 \AA$, $\mathrm{C}(16)-$ $\left.\mathrm{H}(16)=0.95 \AA, \mathrm{C}(16)-\mathrm{H}(16)-\mathrm{Cl}(1)=159^{\circ}\right), \mathrm{Cl}(1) \cdots \mathrm{H}(3 \mathrm{~A})-\mathrm{N}(3)$ $(\mathrm{Cl}(1) \cdots \mathrm{N}(3)=3.29 \AA, \mathrm{N}(3)-\mathrm{H}(3 \mathrm{~A})=0.87 \AA, \mathrm{N}(3)-\mathrm{H}(3 \mathrm{~A})-\mathrm{Cl}(1)=$ $\left.166^{\circ}\right)$, and $\mathrm{Cl}(1) \cdots \mathrm{H}(1)-\mathrm{O}(1)(\mathrm{Cl}(1) \cdots \mathrm{O}(1)=3.09 \AA, \mathrm{O}(1)-\mathrm{H}(1)=$ $\left.0.89 \AA, \mathrm{Cl}(1)-\mathrm{H}(1)-\mathrm{O}(1)=165^{\circ}\right)$.

Previous examples of this type of tridentate dianionic benzimidazolium framework, containing amidate and chiral alkoxide groups, have been used to assemble catalysts that exhibit a variety of interesting properties, such as high enantioselectivities in intermolecular Heck-type coupling reactions, ${ }^{13}$ enantioselectivity reversal in conjugate addition reactions ${ }^{14}$ and high enantioselectivity in Ir-catalyzed transfer hydrogenation. ${ }^{15}$ (The C-O double bond of the amidate group is just a tool to aid synthesizing the ligand: only the nitrogen atom interacts with the metal centre.) Our new approach via rearrangement allows accessing this class of NHC-amino-phenol ligands with facile variation of aryl substituents. For example, a chiral version could be obtained starting from a chiral 1-alkyl-2-amino phenol compound.

A DFT study was performed to help explain the mechanism of this unprecedented rearrangement. Calculations were carried out in the gas phase at the B3LYP/6-31G**//M06-2X/6-31G** level of theory with the Gaussian 09 program $^{16}$ on model compound $\mathbf{4}^{\prime}$ (without $\mathrm{Cl}^{-}$) and $\mathbf{4}^{\prime \prime}$ (with $\mathrm{Cl}^{-}$) in which $\mathrm{Me}$ replaces ${ }^{t} \mathrm{Bu}$ on the hydroxyphenyl group. Single point SMD calculations were also performed in order to take into account solvent (THF) effects (see ESI $\dagger$ ).

Fig. 2 (values in black) presents the energy profile of the rearrangement from $\mathbf{4}^{\prime}$ to $5^{\prime}$ without the counter-ion. Compound $\mathbf{5}^{\prime}$ is found to be the thermodynamically preferred species, more stable than $\mathbf{4}^{\prime}$ by about $15.8 \mathrm{kcal} \mathrm{mol}^{-1}$. The calculations support a two-step pathway passing through a conformer $\mathbf{I}^{\prime}$ located at the same energy as compound $\mathbf{4}^{\prime}$ and having similar geometric parameters except for the rotational orientation of the aniline group (see ESI $\dagger$ ), presumably to bring that $\mathrm{N}$ in a position to interact with the central $\mathrm{C}$. The activation barrier of that first step is low ( $\mathbf{4}^{\prime} \rightarrow$ TS1$^{\prime}$ : $\left.12.6 \mathrm{kcal} \mathrm{mol}^{-1}\right)$ compared to the second one $\left(\mathbf{I} \rightarrow\right.$ TS2$\left.^{\prime}: 32.1 \mathrm{kcal} \mathrm{mol}^{-1}\right)$. Transition state TS2 $^{\prime}$ has structural features intermediate between those of $\mathbf{4}^{\prime}$ and $\mathbf{5}^{\prime}$; it contains two fused five-membered rings with $\mathrm{C}(16)-\mathrm{N}_{\text {Mes }}, \mathrm{C}(16)-\mathrm{N}_{\text {phenolate }}$ and $\mathrm{C}(16)-\mathrm{N}_{\text {phenyl }}$ distances of $1.513 \AA, 1.528 \AA$ and $1.445 \AA$ respectively. The proton (shown as a small sphere), which moves from $\mathrm{N}(1)$ to $\mathrm{N}(3)$ is located approximately equidistant between the two nitrogen atoms (N(1)-H: $1.323 \AA$ and $\mathrm{N}(3)-\mathrm{H}: 1.356 \AA)$ and at $1.726 \AA$ from the $\mathrm{C}(16)$ carbon atom. The calculated overall barrier from $4^{\prime}$ to $5^{\prime}$ of $32.1 \mathrm{kcal} \mathrm{mol}^{-1}$ is much higher than that expected for full conversion in 15 minutes at $90^{\circ} \mathrm{C}$. The reasons are not obvious, except that the ion pairing and hydrogen bond interactions likely are major factors.

With the $\mathrm{Cl}^{-}$counterion included (Fig. 2, values in red), product $\mathbf{5}^{\prime \prime}$ is still thermodynamically preferred over $\mathbf{4}^{\prime \prime}$, 


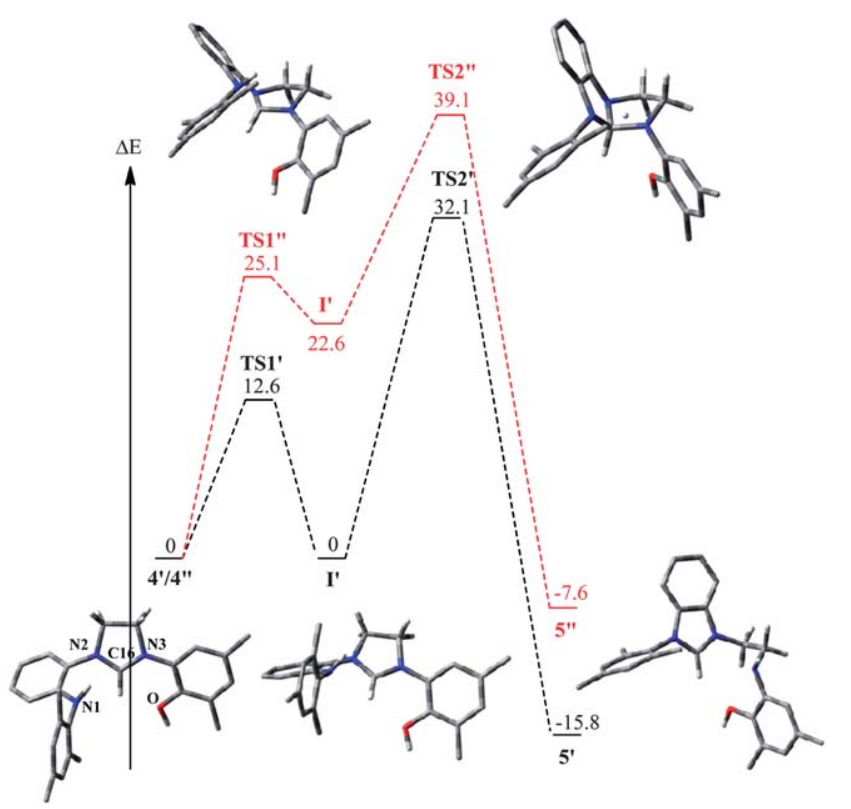

Fig. 2 Energy profile (energy in $\mathrm{kcal} \mathrm{mol}^{-1}$ ) computed at the B3LYP/6-31G**// M06-2X/6-31G** level of theory without the counter-anion (black) and with the counter-anion (red). Some hydrogens have been omitted for clarity. ${ }^{19}$

although by a smaller amount; but both conformer $\mathbf{I}^{\prime \prime}$ and the overall activation barrier are significantly higher in energy. On the other hand, the crystal structure of $\mathbf{5}$ shows stabilization by three $\mathrm{Cl}-\mathrm{H}$ interactions; while those may result strictly from solid-state effects, they suggest at least the possibility that $\mathrm{Cl}^{-}$ could play a role in the rearrangement.

To examine the possible role of the anion in the rearrangement of $\mathbf{4}$, the bis(ammonium) salt of $\mathbf{3}$ was generated using $\mathrm{HBF}_{4}$ instead of $\mathrm{HCl}$. When that was heated with triethyl orthoformate, following the same procedure as for imidazolium 4 (Scheme 1), a white powder again precipitated from solution, but its solubility and NMR properties were quite different from those of $4 .{ }^{17}$ Crystals were obtained from acetone/pentane at low temperature, and X-ray diffraction (Fig. 3) identified the product

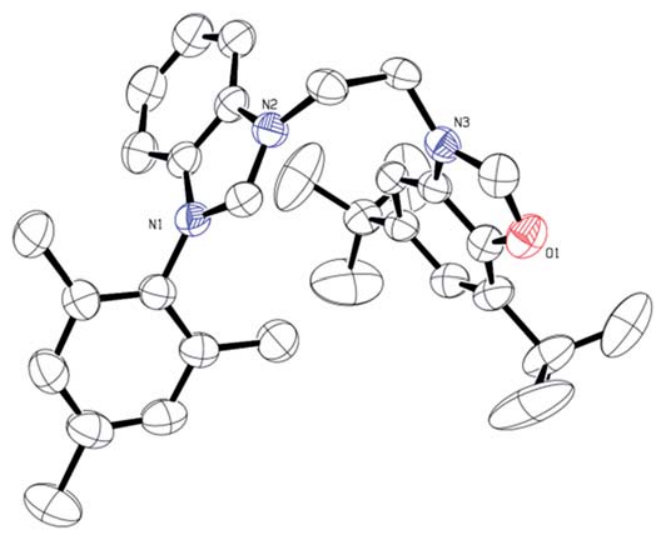

Fig. 3 Molecular structure of benzimidazolium-benzoxazolium bis-tetrafluoroborate 6 . Selected bond lengths $(\AA)$ and angles $\left({ }^{\circ}\right)$ : $N(1)-C(10)=1.327(2)$, $\mathrm{N}(2)-\mathrm{C}(10)=1.321(2), \mathrm{N}(3)-\mathrm{C}(25)=1.304(2), \mathrm{O}(1)-\mathrm{C}(25)=1.305(3), \mathrm{N}(1)-\mathrm{C}(10)-$ $\mathrm{N}(2)=110.93(19), \mathrm{N}(3)-\mathrm{C}(25)-\mathrm{O}(1)=113.0(2)$. The counter-anions $\mathrm{BF}_{4}{ }^{-}$have been omitted for clarity.

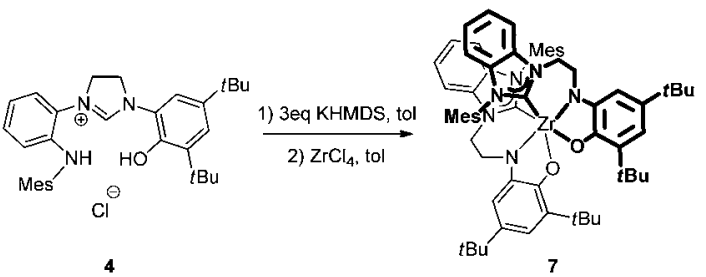

Scheme 2 Synthesis of (CNO)-zirconium complex 7

as benzimidazolium-benzoxazolium bis-tetrafluoroborate salt 6. This appears to be the first example of a bis-NHC ligand containing an (NCN)-(NCO) linkage $;^{18}$ to our knowledge, only four reports of unsymmetrical dicarbenes have appeared, including some evidence for improved catalytic behavior. ${ }^{20}$ The explanation for such a dramatic and unexpected effect of the counter-ion on the nature of the product may lie in the solubility of the monocationic salt: mono(tetrafluoroborate) salts tend to be more soluble than their chloride analogues, allowing them to react further with triethyl orthoformate.

We investigated the tris-deprotonation of the salt $\mathbf{4}$ with strong base (KHMDS) to generate the dianionic carbene in situ followed by its trapping on a zirconium complex (Scheme 2). After work-up, a red powder is obtained in $52 \%$ yield. In the ${ }^{1} \mathrm{H}$ NMR spectrum, the methylene protons range from 4.2 to 2.7 $\mathrm{ppm}$ as four multiplets, somewhat surprisingly dispersed for methylene protons in the $N$-heterocycle. ${ }^{21}$ Nevertheless, the ${ }^{13} \mathrm{C}$ NMR spectrum shows the presence of one carbene signal at $200 \mathrm{ppm}$. Crystals were obtained from a toluene/pentane solution at low temperature and X-ray diffraction (see ESI $\dagger$ ) identified the product as bis(benzimidazolylidene)zirconium complex 7 , resulting from the rearrangement of the imidazolyl unit to a benzimidazolyl moiety followed by bis-ligation. The zirconium metal center exhibits distorted mer-octahedral coordination of the two (CNO) carbene ligands with each NHC trans to its phenolate and the amide groups trans to one another. ${ }^{22}$

Thus, addition of base to salt 4 led to a benzimidazolylidenetype carbene resulting from a rearrangement of the anion analogous to that observed for the imidazolium precursor 4 to 5 , but here involving a deprotonated form of 4 .

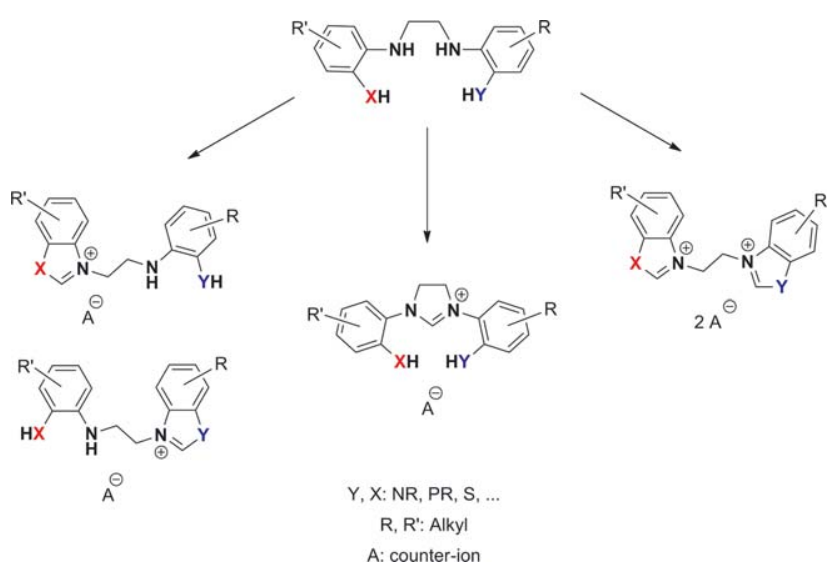

Scheme 3 Strategy to access a library of functionalized carbene precursors. 


\section{Conclusions}

The ability to synthesize three potentially useful carbene precursors starting from the same ethylenediamine species, resulting from an unprecedented intramolecular imidazolium rearrangement and counter-ion effects, offers possibilities for access to a large and varied library of functionalized carbene precursors via an atom-economical process (Scheme 3). Such a rearrangement also occurs during the deprotonation of the imidazolium salt. We were able to isolate a carbene-anilidephenolate zirconium complex showing the ability of a tridentate dianionic carbene ligand to stabilize a hard metal center.

\section{Acknowledgements}

This work was supported by a KAUST Center-In-Development Grant to King Fahd University of Petroleum and Minerals (Dhahran, Saudi Arabia) and the USDOE Office of Basic Energy Sciences (Grant no. DE-FG03-85ER13431). The Bruker KAPPA APEXII X-ray diffractometer was purchased via an NSF CRIF:MU award to the California Institute of Technology, CHE-0639094.

\section{Notes and references}

1 (a) A. Correa, S. P. Nolan and L. Cavallo, Top. Curr. Chem., 2011, 302, 131; (b) V. César, S. Bellemin-Laponnaz and L. H. Gade, Chem. Soc. Rev., 2004, 33, 619; (c) F. Glorius, Top. Organomet. Chem., 2007, 21, 1; (d) D. Bourissou, O. Guerret, F. Gabbaï and G. Bertrand, Chem. Rev., 2000, 100, 39; (e) V. César, L. H. Gade and S. Bellemin-Laponnaz, RSC Catal. Ser., 2011, 6, 228.

2 (a) J. J. Van Veldhuizen, S. B. Garber, J. S. Kingsbury and A. H. Hoveyda, J. Am. Chem. Soc., 2002, 124, 4954; (b) M. Chiang, Y. Li, D. Krishnan, P. Sumod, K. Hong Ng and P.-H. Leung, Eur. J. Inorg. Chem., 2010, 1413; (c) T. Uchida and T. Katsukid, Tetrahedron Lett., 2009, 50, 4741; (d) D. Martin, S. Kehrli, M. d'Augustin, H. Clavier, M. Mauduit and A. Alexakis, J. Am. Chem. Soc., 2006, 128, 8416.

3 (a) O. Kühl, Chem. Soc. Rev., 2007, 36, 592; (b) S. T. Liddle, I. S. Edworthy and P. L. Arnold, Chem. Soc. Rev., 2007, 36, 1732; (c) L.-A. Schaper, E. Tosh and W. A. Herrmann, RSC Catal. Ser., 2011, 6, 166.

4 (a) C. Romain, L. Brelot, S. Bellemin-Laponnaz and S. Dagorne, Organometallics, 2010, 29, 1191; (b) C. Romain, B. Heinrich, S. Bellemin-Laponnaz and S. Dagorne, Chem. Commun., 2012, 48, 2213.

5 (a) H. Aihara, T. Matsuo and H. Kawaguchi, Chem. Commun., 2003, 2204; (b) D. Zhang, G. GengShi, J. Wang, Q. Yue, W. Zheng and L. Weng, Inorg. Chem. Commun., 2010, 13, 433; (c) D. Zhang and N. Liu, Organometallics, 2009, 28, 499; (d) C. Bocchino, M. Napoli, C. Costabile and P. Longo, J. Polym. Sci., Part A: Polym. Chem., 2011, 49, 862; (e) L. P. Spencer and M. D. Fryzuk, J. Organomet. Chem., 2005, 690, 5788; (f) D. S. McGuinness, V. C. Gibson and J. W. Steed, Organometallics, 2004, 23, 6288.

6 (a) D. Zhang, H. Aihara, T. Watanabe, T. Matsuo and H. Kawaguchi, J. Organomet. Chem., 2007, 692, 234; (b)
S. Bellemin-Laponnaz, R. Welter, L. Brelot and S. Dagorne, J. Organomet. Chem., 2009, 694, 604; (c) P. L. Arnold and C. Wilson, Inorg. Chim. Acta, 2007, 360, 190.

7 L. P. Spencer, S. Winston and M. D. Fryzuk, Organometallics, 2004, 23, 3372.

8 (a) D. Sellmann, C. Allmann, F. Heinemann, F. Knoch and J. Sutter, J. Organomet. Chem., 1997, 541, 291; (b) N. Matsumura, J.-L. Kawano, N. Fukunishi, H. Inoue, M. Yasui and F. Iwasaki, J. Am. Chem. Soc., 1995, 117, 3623. 9 J. H. Lee, K. S. Yoo, C. P. Park, J. M. Olsen, S. Sakagushi, G. K. S. Prakash, T. Mathew and K. W. Jung, Adv. Synth. Catal., 2009, 351, 563.

10 Spectroscopic data for 4: ${ }^{1} \mathrm{H}$ NMR $\left(400 \mathrm{MHz}, \mathrm{CDCl}_{3}\right): 9.74(\mathrm{~s}$, $1 \mathrm{H}, \mathrm{OH}), 8.18(\mathrm{~s}, 1 \mathrm{H}, \mathrm{NCHN}), 8.11(\mathrm{~s}, 1 \mathrm{H}, \mathrm{NH}), 7.35(\mathrm{~s}, 1 \mathrm{H}$, $\left.\mathrm{CH}_{\mathrm{Ph}}\right), 7.13\left(\mathrm{~m}, 1 \mathrm{H}, \mathrm{CH}_{\mathrm{Ph}}\right), 7.11\left(\mathrm{~m}, 1 \mathrm{H}, \mathrm{CH}_{\mathrm{Ph}}\right), 6.99(\mathrm{~s}, 1 \mathrm{H}$, $\mathrm{CH}_{\mathrm{Ph}}$ ), $6.89\left(\mathrm{~s}, 2 \mathrm{H}, \mathrm{CH}_{\mathrm{Mes}}\right), 6.67\left(\mathrm{~m}, 1 \mathrm{H}, \mathrm{CH}_{\mathrm{Ph}}\right), 6.28(\mathrm{~m}$, $\left.1 \mathrm{H}, \mathrm{CH}_{\mathrm{Ph}}\right), 4.77\left(\mathrm{~s}, 4 \mathrm{H}, \mathrm{NCH}_{2}\right), 2.28\left(\mathrm{~s}, 3 \mathrm{H}, \mathrm{CH}_{3 \mathrm{Mes}}\right), 2.22(\mathrm{~s}$, $6 \mathrm{H}, \mathrm{CH}_{3 \mathrm{Mes}}$ ), 1.41 (s, 9H, $\left.t \mathrm{Bu}\right), 1.30(\mathrm{~s}, 9 \mathrm{H}, t \mathrm{Bu}) .{ }^{1} \mathrm{H}$ NMR $\left(500 \mathrm{MHz}, \mathrm{MeOH}-\mathrm{d}_{4},-40{ }^{\circ} \mathrm{C}\right): 7.43-7.40$ (m, 3H, CH), 7.17 (pt, $J=7.2 \mathrm{~Hz}, 1 \mathrm{H}, \mathrm{CH}), 7.00(\mathrm{~s}, 2 \mathrm{H}, \mathrm{CH}), 6.78$ (pt, $J=7.2$ $\mathrm{Hz}, 1 \mathrm{H}, \mathrm{CH}), 6.16(\mathrm{~d}, J=8.3 \mathrm{~Hz}, 1 \mathrm{H}, \mathrm{CH}), 4.56(\mathrm{~m}, 2 \mathrm{H}$, $\mathrm{NCH}_{2}$ ), $4.45\left(\mathrm{~m}, 2 \mathrm{H}, \mathrm{NCH}_{2}\right), 2.32$ (s, 3H, $\left.\mathrm{CH}_{3 \mathrm{Mes}}\right), 2.18$ (s, $6 \mathrm{H}, \mathrm{CH}_{3 \mathrm{Mes}}$ ), 1.45 (s, 9H, $\left.t \mathrm{Bu}\right), 1.33(\mathrm{~s}, 9 \mathrm{H}, t \mathrm{Bu}) .{ }^{13} \mathrm{C} \mathrm{NMR}$ (100 MHz, $\mathrm{CDCl}_{3}$ ): 158.1 (NCHN), 148.5 (C), 143.9 (C), 143.3 (C), 142.0 (C), 136.4 (C), 135.7 (C), 134.7 (C), 131.3 $(\mathrm{CH}), 129.4(\mathrm{CH}), 126.6(\mathrm{CH}), 125.3(\mathrm{C}), 125.2(\mathrm{CH}), 120.9$ (C), $118.6(\mathrm{CH}), 117.1(\mathrm{CH}), 114.7(\mathrm{CH}), 52.1\left(\mathrm{NCH}_{2}\right), 50.2$ $\left(\mathrm{NCH}_{2}\right), 35.8(t \mathrm{Bu}), 34.6(t \mathrm{Bu}), 31.6(t \mathrm{Bu}), 29.9(t \mathrm{Bu}), 21.1$ $\left(\mathrm{CH}_{3 \mathrm{Mes}}\right), 18.7$ ( $\left.\mathrm{CH}_{3 \mathrm{Mes}}\right)$.

11 B. A. B. Prasad and S. R. Gilbertson, Org. Lett., 2009, 11(16), 3710.

12 Spectroscopic data for 5: ${ }^{1} \mathrm{H}$ NMR (400 $\mathrm{MHz}$, toluene $\mathrm{d}_{8}$ ): 11.65 (s, 1H, NCHN), 8.66 (s, 1H, OH), 7.64 (d, $J=8.2 \mathrm{~Hz}$, $\left.1 \mathrm{H}, \mathrm{CH}_{\mathrm{Ph}}\right), 7.13\left(\mathrm{t}, J=7.8 \mathrm{~Hz}, 1 \mathrm{H}, \mathrm{CH}_{\mathrm{Ph}}\right), 6.88(\mathrm{t}, J=7.8$ $\left.\mathrm{Hz}, 1 \mathrm{H}, \mathrm{CH}_{\mathrm{Ph}}\right), 6.82\left(\mathrm{~m}, 1 \mathrm{H}, \mathrm{CH}_{\mathrm{Ph}}\right), 6.66\left(\mathrm{~s}, 2 \mathrm{H}, \mathrm{CH}_{\mathrm{Mes}}\right)$, $6.44\left(\mathrm{~d}, J=8.2 \mathrm{~Hz}, 1 \mathrm{H}, \mathrm{CH}_{\mathrm{Ph}}\right), 6.33$ (br.s, 1H, NH), 6.21 (s, $\left.1 \mathrm{H}, \mathrm{CH}_{\mathrm{Ph}}\right), 5.13\left(\mathrm{~m}, 2 \mathrm{H}, \mathrm{NCH}_{2}\right), 3.57\left(\mathrm{~m}, 2 \mathrm{H}, \mathrm{NCH}_{2}\right), 2.07$ $\left(\mathrm{s}, 3 \mathrm{H}, \mathrm{CH}_{3}\right), 1.83\left(\mathrm{~s}, 6 \mathrm{H}, \mathrm{CH}_{3}\right), 1.65(\mathrm{~s}, 9 \mathrm{H}, t \mathrm{Bu}), 1.12(\mathrm{~s}$, $9 \mathrm{H}, t \mathrm{Bu}) .{ }^{13} \mathrm{C}$ NMR (100 MHz, toluene- $\left.\mathrm{d}_{8}\right): 147.1(\mathrm{NCHN})$, 142.3 (C), 141.6 (C), 140.7 (C), 138.6 (C), 137.2 (C), 136.5 (C), 131.8 (C), 131.3 (C), $129.9(\mathrm{CH}), 126.7(\mathrm{CH}), 126.6$ $(\mathrm{CH}), 125.2(\mathrm{C}), 114.2(\mathrm{CH}), 112.7(\mathrm{CH}), 112.3(\mathrm{CH}), 105.7$ $(\mathrm{CH}), 48.7\left(\mathrm{NCH}_{2}\right), 42.2\left(\mathrm{NCH}_{2}\right), 35.5(t \mathrm{Bu}), 34.5(t \mathrm{Bu}), 31.9$ $(t \mathrm{Bu}), 30.6(t \mathrm{Bu}), 21.1\left(\mathrm{CH}_{3}\right), 17.7\left(\mathrm{CH}_{3}\right)$.

13 (a) S. Sakaguchi, K. S. Yoo, J. O'Neil, J. H. Lee, T. Steward and K. W. Jung, Angew. Chem., Int. Ed., 2008, 47, 9326; (b) K. S. Yoo, J. O'Neil, S. Sakaguchi, R. Giles, J. H. Lee and K. W. Jung, J. Org. Chem., 2010, 75, 95.

14 (a) M. Yoshimura, N. Shibata, M. Kawakami and S. Sakaguchi, Tetrahedron, 2012, 68, 3512; (b) N. Shibata, M. Yoshimura, H. Yamada, R. Arakawa and S. Sakaguchi, J. Org. Chem., 2012, 77, 4079; (c) N. Shibata, O. Masaki, Y. Yamamoto and S. Sakaguchi, J. Org. Chem., 2010, 75, 5707; (d) M. Okamoto, Y. Yamamoto and S. Sakaguchi, Chem. Commun., 2009, 7363.

15 (a) S. Kawabata, H. Tokura, H. Chiyojima, M. Okamoto and S. Sakaguchi, Adv. Synth. Catal., 2012, 354, 807; (b) 
H. Chiyojima and S. Skaguchi, Tetrahedron Lett., 2011, 52, 6788.

16 (a) M. J. Frisch, G. W. Trucks, H. B. Schlegel, G. E. Scuseria, M. A. Robb, J. R. Cheeseman, G. Scalmani, V. Barone, B. Mennucci, G. A. Petersson, H. Nakatsuji, M. Caricato, X. Li, H. P. Hratchian, A. F. Izmaylov, J. Bloino, G. Zheng, J. L. Sonnenberg, M. Hada, M. Ehara, K. Toyota, R. Fukuda, J. Hasegawa, M. Ishida, T. Nakajima, Y. Honda, O. Kitao, H. Nakai, T. Vreven, J. A. Montgomery, Jr, J. E. Peralta, F. Ogliaro, M. Bearpark, J. J. Heyd, E. Brothers, K. N. Kudin, V. N. Staroverov, R. Kobayashi, J. Normand, K. Raghavachari, A. Rendell, J. C. Burant, S. S. Iyengar, J. Tomasi, M. Cossi, N. Rega, J. M. Millam, M. Klene, J. E. Knox, J. B. Cross, V. Bakken, C. Adamo, J. Jaramillo, R. Gomperts, R. E. Stratmann, O. Yazyev, A. J. Austin, R. Cammi, C. Pomelli, J. W. Ochterski, R. L. Martin, K. Morokuma, V. G. Zakrzewski, G. A. Voth, P. Salvador, J. J. Dannenberg, S. Dapprich, A. D. Daniels, Ö. Farkas, J. B. Foresman, J. V. Ortiz, J. Cioslowski, and D. J. Fox, Gaussian 09, Revision C.01, Gaussian, Inc., Wallingford CT, 2009; (b) See ESI $\dagger$ for details of the calculations.

17 Spectroscopic data for 6: ${ }^{1} \mathrm{H}$ NMR (400 MHz, acetone- $\mathrm{d}_{6}$ ): $10.56(\mathrm{~s}, 1 \mathrm{H}, \mathrm{NCH}), 9.58(\mathrm{~s}, 1 \mathrm{H}, \mathrm{NCH}), 8.64\left(\mathrm{~m}, 1 \mathrm{H}, \mathrm{CH}_{\mathrm{Ph}}\right)$, $7.99\left(\mathrm{~m}, 1 \mathrm{H}, \mathrm{CH}_{\mathrm{Ph}}\right), 7.88\left(\mathrm{~m}, 1 \mathrm{H}, \mathrm{CH}_{\mathrm{Ph}}\right), 7.77\left(\mathrm{~s}, 1 \mathrm{H}, \mathrm{CH}_{\mathrm{Ph}}\right)$, $7.55\left(\mathrm{~m}, 2 \mathrm{H}, \mathrm{CH}_{\mathrm{Mes}}\right), 7.15\left(\mathrm{~s}, 2 \mathrm{H}, \mathrm{CH}_{\mathrm{Ph}}\right), 5.80$ (pt, $J=6.1$ $\mathrm{Hz}, 2 \mathrm{H}, \mathrm{NCH}_{2}$ ) 5.66 (pt, $J=6.1 \mathrm{~Hz}, 2 \mathrm{H}, \mathrm{NCH}_{2}$ ), 2.36 (s, $\left.3 \mathrm{H}, \mathrm{CH}_{3}\right), 1.71\left(\mathrm{~s}, 6 \mathrm{H}, \mathrm{CH}_{3}\right), 1.54(\mathrm{~s}, 9 \mathrm{H}, t \mathrm{Bu}), 1.16(\mathrm{~s}, 9 \mathrm{H}$, $t \mathrm{Bu}) .{ }^{13} \mathrm{C}$ NMR (100 MHz, acetone- $\left.\mathrm{d}_{6}\right): 159.5(\mathrm{NCH}), 154.1$ (C), 146.8 (C), 144.9 (NCH), 142.6 (C), 138.3 (C), 136.4 (C),
$132.9(\mathrm{C}), 132.2(\mathrm{C}), 130.8(\mathrm{CH}), 130.1(\mathrm{CH}), 129.7(\mathrm{CH})$, $129.4(\mathrm{C}), 128.9(\mathrm{CH}), 125.8(\mathrm{CH}), 115.6(\mathrm{CH}), 114.8(\mathrm{CH})$, $108.9(\mathrm{CH}), 48.0\left(\mathrm{NCH}_{2}\right), 46.2\left(\mathrm{NCH}_{2}\right), 36.5(t \mathrm{Bu}), 35.6$ $(t \mathrm{Bu}), 31.5(t \mathrm{Bu}), 30.1(t \mathrm{Bu}), 21.2\left(\mathrm{CH}_{3}\right), 17.1\left(\mathrm{CH}_{3}\right)$.

18 For an interesting example of an $\mathrm{N}, \mathrm{O}$-heterocyclic carbene, see: S. Bellemin-Laponnaz, Polyhedron, 2010, 29, 30.

19 A clearer version of the diagram and molecular structures may be found in the ESI (Fig. S2 $\dagger$ ).

20 (a) M. T. Zamora, M. J. Ferguson, R. McDonald and M. Cowie, Organometallics, 2012, 31, 5463; (b) T. A. P. Paulose, J. A. Olson, J. W. Quail and S. R. Foley, J. Organomet. Chem., 2008, 693, 3405; (c) S. S. Khan and J. Liebscher, Synthesis, 2010, 2609; (d) R. Wang, C. M. Jin, B. Twanley and J. M. Shreeve, Inorg. Chem., 2006, 45, 6396.

21 Spectroscopic data for 7: ${ }^{1} \mathrm{H}$ NMR (400 MHz, $\left.\mathrm{C}_{6} \mathrm{D}_{6}\right): 6.97$ (s, $2 \mathrm{H}, \mathrm{CH}), 6.96(\mathrm{~s}, 2 \mathrm{H}, \mathrm{CH}), 6.86(\mathrm{~d}, J=2.1 \mathrm{~Hz}, 2 \mathrm{H}, \mathrm{CH})$, $6.79(\mathrm{~s}, 2 \mathrm{H}, \mathrm{CH}), 6.74(\mathrm{~m}, 2 \mathrm{H}, \mathrm{CH}), 6.53(\mathrm{~s}, 2 \mathrm{H}, \mathrm{CH}), 6.30$ (d, $J=8.2 \mathrm{~Hz}, 2 \mathrm{H}, \mathrm{CH}), 6.06(\mathrm{~d}, J=2.1 \mathrm{~Hz}, 2 \mathrm{H}, \mathrm{CH}), 4.20$ $\left(\mathrm{m}, 2 \mathrm{H}, \mathrm{NCH}_{2}\right), 3.62\left(\mathrm{~m}, 2 \mathrm{H}, \mathrm{NCH}_{2}\right), 3.40\left(\mathrm{~m}, 2 \mathrm{H}, \mathrm{NCH}_{2}\right)$, $2.75\left(\mathrm{~m}, 2 \mathrm{H}, \mathrm{NCH}_{2}\right), 2.29\left(\mathrm{~s}, 6 \mathrm{H}, \mathrm{CH}_{3}\right), 1.66(\mathrm{~s}, 36 \mathrm{H}, t \mathrm{Bu})$, $1.30\left(\mathrm{~s}, 6 \mathrm{H}, \mathrm{CH}_{3}\right), 0.86\left(\mathrm{~s}, 6 \mathrm{H}, \mathrm{CH}_{3}\right) .{ }^{13} \mathrm{C} \mathrm{NMR}(151 \mathrm{MHz}$, $\left.\mathrm{C}_{6} \mathrm{D}_{6}\right)$ : 200.1 ( $\left.\mathrm{C}_{\text {carb}}\right), 153.6$ (C), 152.3 (C), 139.7 (C), 139.5 (C), 138.1 (C), 135.1 (C), 134.4 (C), 133.7 (C), 133.4 (C), $131.4(\mathrm{CH}), 130.9(\mathrm{C}), 128.3(\mathrm{CH}), 124.4(\mathrm{CH}), 124.1(\mathrm{CH})$, $111.7(\mathrm{CH}), 111.1(\mathrm{CH}), 110.5(\mathrm{CH}), 104.7(\mathrm{CH}), \quad 50.5$ $\left(\mathrm{NCH}_{2}\right), 47.4\left(\mathrm{NCH}_{2}\right), 35.1(t \mathrm{Bu}), 35.0(t \mathrm{Bu}), 33.0(t \mathrm{Bu}), 30.4$ $(t \mathrm{Bu}), 21.3\left(\mathrm{CH}_{3}\right), 17.7\left(\mathrm{CH}_{3}\right), 16.9\left(\mathrm{CH}_{3}\right)$.

22 The poor quality of the crystals, even after several attempts at recrystallization, precludes accurate determination of parameters. 